University of Nebraska - Lincoln

DigitalCommons@University of Nebraska - Lincoln

Faculty Papers and Publications in Animal

Science

Animal Science Department

2017

\title{
144 EFFECT OF ANTRAL FOLLICLE COUNT IN BEEF HEIFERS ON IN VITRO FERTILIZATION/PRODUCTION
}

C. C. Chase Jr.

USDA-ARS, Chad.Chase@ars.usda.gov

R. A. Freeland

USDA-ARS, Bob.Cushman@ars.usda.gov

A. K. McNeel

USDA-ARS

E. C. Wright-Johnson

USDA-ARS

G. A. Perry

South Dakota State University, George.Perry@sdstate.edu

See next page for additional authors

Follow this and additional works at: https://digitalcommons.unl.edu/animalscifacpub

Part of the Genetics and Genomics Commons, and the Meat Science Commons

Chase, C. C. Jr.; Freeland, R. A.; McNeel, A. K.; Wright-Johnson, E. C.; Perry, G. A.; Tenley, S. C.; Wood, J. R.; Cupp, A. S.; Vallet, J. L.; and Miles, J. R., "144 EFFECT OF ANTRAL FOLLICLE COUNT IN BEEF HEIFERS ON IN VITRO FERTILIZATION/PRODUCTION" (2017). Faculty Papers and Publications in Animal Science. 935. https://digitalcommons.unl.edu/animalscifacpub/935

This Article is brought to you for free and open access by the Animal Science Department at DigitalCommons@University of Nebraska - Lincoln. It has been accepted for inclusion in Faculty Papers and Publications in Animal Science by an authorized administrator of DigitalCommons@University of Nebraska Lincoln. 


\section{Authors}

C. C. Chase Jr., R. A. Freeland, A. K. McNeel, E. C. Wright-Johnson, G. A. Perry, S. C. Tenley, J. R. Wood, A. S. Cupp, J. L. Vallet, and J. R. Miles 
http://www.publish.csiro.au/RD/RDv29n1Ab144

Reproduction, Fertility and Development

Volume 29 Number 12017

Proceedings of the Annual Conference of the International Embryo Technology Society, Austin, Texas, 14-17 January 2017

Full Papers and Abstracts for Poster Presentation

\section{EFFECT OF ANTRAL FOLLICLE COUNT IN BEEF HEIFERS ON IN VITRO FERTILIZATION/PRODUCTION}

C. C. Chase, Jr. ${ }^{\text {A }}$, R. A. Cushman ${ }^{\text {A }}$, A. K. McNeel $^{\text {A }}$, E. C. Wright-Johnson ${ }^{\text {A }}$, G. A. Perry ${ }^{\text {B }}$, S. C. Tenley ${ }^{\text {C }}$, J. R. Wood ${ }^{\text {C }}$, A. S. Cupp ${ }^{\text {C }}$, J. L. Vallet ${ }^{\text {A }}$ and J. R. Miles ${ }^{\text {A }}$

A USDA-ARS, U.S. Meat Animal Research Center, Clay Center, NE, USA;

B Department of Animal Science, South Dakota State University, Brookings, SD, USA;

${ }^{\mathrm{C}}$ Department of Animal Science, University of Nebraska, Lincoln, Lincoln, NE, USA

Reproduction, Fertility and Development 29(1) 180-180

http://dx.doi.org/10.1071/RDv29n1Ab144

Published: 2 December 2016

\section{Abstract}

Our objective has been to compare the IVF and in vitro production (IVP) of embryos from low and high antral follicle count (AFC) heifers. This is the fourth year of the study with years 1 to 3 reported individually. For this report, we add data for the fourth year and present a combined analysis (years 1 to 4 ) for the first time. Each year, AFC was determined on $\sim 120$ Angus heifers using transrectal ultrasonography. Ten heifers with the lowest AFC and 10 heifers with the highest AFC and all with evidence of oestrous cyclicity were synchronized with two 5-mL injections of $\mathrm{PGF}_{2 \alpha} 11$ days apart. Half were harvested on Day 5 to 6 and half on Day 15 to 16 of the oestrous cycle. The IVF procedure was slightly modified each year. For year 4, the IVF procedure included protocols for semi-defined media and was as described (IVP Protocol, P. J. Hansen's Laboratory, University of Florida). Cumulus-oocyte complexes (COC) from follicles less than $8 \mathrm{~mm}$ in diameter were cultured in maturation medium $\left(5 \% \mathrm{CO}_{2} ; 38.5^{\circ} \mathrm{C}\right)$ for $24 \mathrm{~h}$. 
Matured COC were fertilized using thawed frozen semen from a bull that was purified using isolate. Motile spermatozoa were added to $\mathrm{COC}$ in fertilization medium at a final concentration of $1 \times 10^{6}$ spermatozoa per $\mathrm{mL}$. About $24 \mathrm{~h}$ later, presumptive zygotes were placed in micro drops of development medium under oil, and cultured $\left(5 \% \mathrm{CO}_{2} ; 5 \% \mathrm{O}_{2}\right.$; balance $\left.\mathrm{N}_{2} ; 38.5^{\circ} \mathrm{C}\right)$. On Day 3 and 8 after fertilization, cleavage and blastocyst development rates, respectively, were assessed. Data were analysed using the MIXED procedure of SAS (SAS Institute Inc., Cary, NC, USA) and the model included the effects of year (1 to 4), group (high or low AFC), and their interaction. The year $\times$ group interaction was not significant $(P>0.10)$. Low AFC heifers, compared with high AFC heifers, had fewer numbers of COC $(P<0.0001 ; 12.8 \pm 1.83 v$. $31.9 \pm 1.86)$, fewer numbers of COC that cleaved $(P<0.0001 ; 8.0 \pm 1.38 v .21 .6 \pm 1.40)$, and fewer numbers of COC that developed to the blastocyst stage $(P<0.0001 ; 1.7 \pm 0.58 v$. $5.7 \pm 0.58)$. Year affected the numbers of COC that cleaved $(P<0.003)$ and the numbers of COC that developed to the blastocyst stage $(P<0.0001)$. Year also influenced the percentage of COC that cleaved $(P<0.0002)$ and the percentage of COC that developed to blastocysts $(P<0.0001)$. Group (AFC) did not influence $(P>0.19)$ the percentage of COC that cleaved $(61.2 \pm 2.83 v$. $66.4 \pm 2.83 \%$, for low $v$. high AFC, respectively). Low AFC heifers had a lower $(P<0.002)$ percentage of $\mathrm{COC}$ that developed to blastocysts $(10.3 \pm 1.52 \%)$ than high $\mathrm{AFC}$ heifers $(17.6 \pm 1.52 \%)$. These results indicate that high AFC heifers, compared to low AFC heifers, have more $\mathrm{COC}$ recovered, more $\mathrm{COC}$ cleaved, and more $\mathrm{COC}$ developed to the blastocyst stage. The percentage of COC cleaved did not differ between AFC groups; however, the percentage of COC that developed to the blastocyst stage was greater for high than low AFC heifers. This suggests a potential advantage in maternal to embryonic transition for high compared with low AFC heifers. 